\title{
The Shameless Dance Cannot Last Forever
}

Kinga Dunin 
Kinga Dunin

\section{The Shameless Dance Cannot Last Forever}

DOI:10.18317/td.2018.en.1.11

$M$ emoirs from a Time of Immaturity (the 1933 edition) was my first encounter with Gombrowicz's then forbidden work. To this day, I remember my high school fascination with Lawyer Kraykowski's Dancer. Then the book got lost somewhere and I returned to the stories only in 1986, with the publication of Jan Błoński's edition of Gombrowicz's works. It is this very edition I am looking at right now, no longer titled Memoirs... but Bacacay. Today, the story, which I know almost by heart, appears to me in a slightly different context. It seems less revolutionary than it was when I read it again in the 1980s. It begins with the protagonist being publicly embarrassed; then, suddenly, "something shifted" in him and he is no longer governed by shame. Quite the contrary.

Sociology believes guilt and shame to be internalized mechanisms of social control. A sense of guilt is supposedly the nobler of the twins, related to a well developed conscience and a stronger internal autonomy. Shame is the lesser of the siblings, the one which looks up to others, determined externally and trembling before social opinion. I am not convinced by this distinction. Maybe guilt is just a sublimated rationalization of shame which in turn is the actual measure of our real relation to the society. It is shame that turns us into conformists, but without conformism, any kind of social cohesion becomes impossible.
Kinga Dunin sociologist, journalist, literary critic. Co-author and coeditor of Cudze problemy. O ważności tego, co nieważne. Author of numerous publications, among them: Tao gospodyni domowej, Karoca z dyni (shortlisted for the Nike Literary Award in 2001), Zadyma, Kochaj i rób, and Czytając Polskę. Literatura polska po roku 1989 wobec dylematów nowoczesności (PhD dissertation).

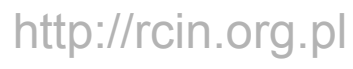


Shame is a natural reflex of the socialized human being. Its manifestations, however, are diverse and specific to time periods, cultures, and groups. Also "shamelessness," "anti-shame" in other words, are instances when we are shamed but question the environment's right to do so. Such instances are specific and individualized. It is a psychologically difficult act, since, as mentioned before, it is a deeply ingrained reflex and to get rid of shame means to become socially uprooted.

Shame defines our boundaries and shamelessness is something more than simply a lack of shame. Shamelessness crosses the boundaries, but it is aware of them. Tell me what you are ashamed of and I will know your place in society and the laws that govern your life. Tell me what you do not want to feel ashamed of, and I will know where you want to be.

Shamelessness can take the form of excess, rebellion, or withdrawal when we cut ourselves off from those trying to shame us. There are many ways to be shameless.

\section{The Shamelessness of Lawyer Kraykowski}

Lawyer Kraykowski (whose surname spelled with a " $y$ " elevates him to the level of aristocracy, above other ordinary Krajkowskis) has nothing to be ashamed of - he embodies self confidence, good taste, and success. He is firmly - almost cartoonishly - rooted in "respectability" and superiority. $\mathrm{He}$ finds himself on the side of social power which decides what is to be viewed as shameful, while operating shamelessly itself. Kraykowski is the one making claims, and in fact his entire character is one of entitlement. He speaks in the name of legitimate societal unity, a complex universe, and fulfills the social mission of guarding the world order.

"We need order! This is Europe!" And, turning to the ladies, he remarked:

"We must teach, teach indefatigably; otherwise we shall never cease to be a nation of Zulus."1

Lawyer Kraykowski is the one who demands subordination from the Other, the inferior. Shame is the instrument of his power.

\section{Shamelessness of the Dancer}

This is met with excess - with surfeit and transgression. The transgression of rules allows the shamed person to retain some dignity by being given

1 Witold Gombrowicz, Bacacay, trans. Bill Johnston (New York: Archipelago Books, 2004), 5. 
nothing more than a mild reprimand; or silence is enforced when shaming is directed at a child or a someone of a much lower social status. Yet, demands can be met with a surplus of what has been demanded. In the story, the Dancer gives the Lawyer what the latter really wanted.

Imagine that at every step he comes across indications of a cult, he meets homage and service all around, loyalty and an iron sense of duty, remembrance. ${ }^{2}$

Thus, the Dancer exposes the essence of shame, which is the power of social conventions over the individual. Violence is inscribed in the procedure of shaming. By meeting the demand with surplus, the victim becomes the oppressor not through resistance, but through an obscene refusal to resist.

But is this strategy also not the reason for the victim's failure?

Shame is often associated with anger on the part of the shamed individual. When suppressed anger becomes destructive, once released, it can dismantle boundaries and redefine power relations. The distinction we make between "unacceptable aggression" and "righteous anger" results strictly from our worldview, as only some constraints are seen as worth shedding. But if the Dancer's strategy seems tempting, we must not forget what can be lost as a result - such a strategy castrates us by removing anger, an emotion which is not unequivocally evil.

A lot of emphasis is put today on the role of contracts in mitigating, or lessening, contemporary contradictions. The phenomenal popularity of 50 Shades of Grey may serve as a good example: the heroine of the novel signs a sadomasochistic contract with her lover. If one consents, does violence cease to be violence? Or not? Or maybe the problem lies in the very consent to violence?

Did Lawyer Kraykowski and his Dancer enter into a contract? It does not seem they did. Pursued by his follower, the Lawyer must escape. On the other hand, the situation presented in the story is far from clear. The strategy of the narrator, revealing a paradoxical victory of inferiority over superiority, is not the strategy of the protagonist. The latter behaves as if he had excessively internalized the violent character of the relation with the oppressor. This is why he is shameless: he seems to have accepted the cultural contract with excessive enthusiasm. However, a contract remains a contract.

It seems that shame can be dealt away with through an acceptance of subordination, a kind of exaggerated and excessive submissiveness. (Yes, I am talking about homosexual and campy excesses). But what is the power

2 Ibid., 10. 
balance between submissiveness and exaggeration? In what conditions can it become an instrument of emancipation or transgression?

\section{Shamelessness of Lovetown}

This, of course, is tied to the question of whether camp as a poetics really is emancipatory. It is certainly a good idea to investigate Michał Witkowski's Lovetown (2005) in this context.

The critics swooned over Lovetown, and the readers loved all the colorful aunties of the Polish People's Republic (PRL), even though they were quite horrible characters: lustful, envious, ostentatious, willing to break all standards, ready to steal, deceive, or kill. But they also have become a provocative and liberating symbol - responding to the shame of homosexuality, "femininity," and marginalization by ostensibly adopting assigned roles. By responding with excess, with women's clothes, they answered decency with indecency, and reacted to shaming by flaunting shamelessnes through showy displays. Still, let us not forget that we are dealing not with the realities of the PRL, but with a narrative created in the early twenty-first century. And even then, Lovetown was already an anti-emancipatory text, mocking contemporary movements for equality. The novel supported the strategy of queering one's identity as opposed to the constructive, rightful anger of the LGTBQ activists.

\section{The Shamelessness of Capitalism}

Lovetown's gays lived in a world of their own; in bushes, public toilets, and dingy clubs, invisible even when they were seen. There was even no language to talk about them. They lived in opposition to the whole monotone, oppressive order. However, capitalism works differently - it can absorb and neutralize all eccentricity. Contemporary capitalist culture is embodied not by the poularde-eating Lawyer Kraykowski, whose form and boundaries are clearly defined, but by a much more fluid, protean hybridity, ready to swallow rather than spit. Of course, only for a time.

In Witkowski's latest novel, Fynf und cwancyś (2015), the PRL aunties are replaced with other, although quite similar, characters - young Eastern European boys prostituting themselves in the early 1990s in Germany, Austria, and Switzerland.

In the world of sated, self-satisfied capitalism rushing full steam ahead, boy prostitutes are not an alien body. They are simply an element of the system, only a little more spicy than the rest, being gay after all. In capitalism, whoring is not as much a transgression as it is a norm. It may seem surprising 
only in its homosexual form: old, unattractive men pay for the bodies of young boys, as well as several other illusions, with the money inherited from their often fascist ancestors, or earned in banks profiting from sham loans. The boys sell their bodies, but also various false stories and masks hiding their real faces. You can get anything you want in this world: chocolate cows, golden gadgets, fancy labels, limousines, fountains, and even gluten-free dog food you just need to have the means to get it. How you do it is unimportant. It is the end result that matters. Witkowski's protagonist, Michał - also known, for his penis size, as "Fynf und cfancyś" [twenty-five] - gets it all, not only with the help of his fynf und cfancyś, but also by being clever and cynical. He gets it all, or at least brags about it. Another character, Dianka, loses and quickly becomes nothing more than a piece of trash to be shoved back, with the other trash of Western Europe, to the East. There is no place for the aunties of Lovetown in the whorish capitalism that chokes on its own well-being. It is a world you join or else become garbage, waste. And the narrator remarks more than once, the whole thing is not about sex.

Dianka seems to be Michal's second, shameful face. But it is neither his homosexuality, nor profession, that are the cause of shame. What is shameful is the lack of success.

Everything is exaggerated in Witkowski's novel, sometimes even grotesquely, filled with irony and ... beautifully prepped for sale. You will find product placement on the pages, and sometimes a character asks how much he is going to be paid for appearing in the book. The author clearly knows what he is doing.

\section{The Shamelessness of Michaśka}

Wiśniewski has continued to write Lovetown on his own body. Dressed as an old auntie - Michaśka - he has long teased reality through cheap thrills: provocation, tabloid media, fashion, exaggeration, kitsch, and stupidity, and for a long time he did it with impunity. It did end with a scandal though. The publication of Fynf und cfancys was delayed due to public criticism and a complaint filed at the prosecutor's office. Having appeared at a fashion gala wearing a cap adorned with the SS emblem, Witkowski was accused of propagating Nazism and became a victim of a vicious Internet campaign; all of this was reported also by the non-tabloid media and aroused deep and holy indignation in a lot of people. Others, the more tolerant ones, viewed his behavior as simply stupid and distasteful, something deserving nothing more than a slightly dismissive reproach, which ultimately differs little from contempt. Witkowski himself apologized and claimed being unaware of his headwear, which was supposedly selected by the stylist. He behaved as someone effectively shamed and called to order. 
A formal repentance, irrespective of the real emotions, signals a submission to the social demand.

No one attempted to interpret the writer's behavior as something other than a desire to provoke or an instance of primitive self-promotion. However, Witkowski's styling, regardless of his intentions, may have another layer of significance.

The stripes on his cap were diagonal but they also bring to mind the clothes of prisoners in the concentration camp. Also, they were pink, just as the triangle used by the Nazis to stigmatize homosexuals. An SS emblem, adorned with tawdry ornaments, placed against such background becomes devoid of its original meaning, it is "queered," ridiculed. Its meaning transforms, disturbing and violating the sacrum: of gender, of the Holocaust, of our attitude to the menacing symbol. It is like a pin touching the bubble of pathos; exaggeration assaulting the boundaries of good taste which sometimes also protect hypocrisy. Why exactly were so many upset? And why was no one able to clearly express what was so disturbing about the act (the accusations of "propagating Nazism" being clearly absurd)?

Witkowski's fateful cap combined parodied symbols related to two important spheres of the social sacrum. The prison stripes evoke associations with martyrdom - that of the Polish nation, of the Jews - but rarely the martyrdom of homosexuals. This is the first strike on the sacrum. But is the space in question really sanctified to the degree that forbids jest? In literature, cinematography, and art, shielded by their seriousness, subjects such as this are presented in tonalities found also in popular and commercial genres, sometimes becoming a hotbed of kitsch, a pornographization of suffering. Michaśka's frivolous use of symbolism forces a reflection on the boundaries of good taste: is Jerzy Kosiński's The Painted Bird a great work of art or an instance of scandalously pornographic violence?

The relation between the symbols of martyrdom and cruelty (Nazism, the SS) reflect the relation of the victim and the oppressor. However, the violence in question and the figure of the SS-Mann are also the subject of fascination, sometimes very well hidden, sometimes much less so.

The issues of pop culture, kitsch, and Nazi symbolism, the pornography and homo-erotism of boys dressed in German uniforms (designed by Hugo Boss) are well suited for various types of analyses. Sometimes they become the subject of high art. Fascist symbolism, associated with sexuality, is a topos found in literature and visual arts, from their highly sophisticated varieties to the most pedestrian ones, a spectrum encompassing horror, sublimated disgust, ironic and romantic (!) uses, comedy, gross vulgarity, and pornography. Witkowski simply revealed all that. Do not ask him if his goal was subversion, queer, or camp. He either created Michaśka, and her subsequent, stupid, 
embarrassing, and kitschy incarnations, or he simply is Michaśka. Michaśka/ Michał and her life art, whether intentionally or not (this does not matter really), are a part of this world and its caricature.

\section{The Limits of Shamelessness}

One could say it was all a storm in a teacup, almost entirely forgotten today. Like many similar events, it provided some short-lived excitement and was replaced by another, and then yet another one.

Literature and art constitute fields of culture where Lawyer Kraykowski's Dancer can dance shamelessly and even achieve a symbolic victory. Had Michaśka's cap been placed in an art gallery, it would have surely resulted in interesting critical analyses. As a symbol, it is so complex that Olbrychski probably would not try to attack it with his saber. ${ }^{3}$ After all, it is a sphere where nothing happens for real, an autonomous world of symbols, although one would wish it to be far less autonomous sometimes.

Similar opportunities can be found in academic discourse. With its veil of jargon, it allows one to discuss, safely (and shamelessly), subjects which would otherwise be seen as disturbing or controversial. The academic discourse, as literature and art do, allows for more, but this comes at a price of having no influence on reality.

The world of tabloid celebrities, shady elites, fashion foolery, and events for the chosen few is also - despite what it seems - a protective zone. Here we know from the start that we are dealing with entertainment, or a hoax, instead of meaningful symbols of higher culture. However, paradoxically, it is her inferiority that allowed Michaśka's gesture to be recognized by the sphere of ideological and political discourse (something that a few serious artists have also managed to achieve.) I cannot recall any fictional literary work which has provoked similar uproar, even though Witkowski's current work is sometimes even more vulgar and shameless than his performances in real life.

But what results from such interventions into other social fields?

Nothing really. If any sense was to be discovered in it, it has already been digested by the mechanisms of dominant discourses, and is now well-encysted. All procedures of shaming worked with full force. Shamelessness revealed itself to be a convention attributed to certain social fields and not a privilege of the individual.

Michaśka's example also reveals the mechanisms of social control. Emotions appear as a reflexive indignation related to the violation of sacralized

3 In June 2002, Polish actor Daniel Olbrychski attacked with a sabre a series of photographs portraying actors who played Nazi officers in the movies [trans.] 
cultural signs. The norm is found only later, even one as absurd as the "prohibition against propagating fascism," and it is an act of ex post rationalization, as are the expressions of "disgust" and dismissals of Witkowski's "stupidity," which similarly refuse to look for other possible explanations. What is hidden beneath? Homophobia, probably, but also (perhaps more importantly) an attempt to defend the boundaries. There is no holiness without the possibility of blasphemy.

Social rules determine whether blasphemy has taken place, and they are not always entirely clear. Work on the border of what is "allowed" and "forbidden" leads first to shamelessness and can potentially broaden the scope of the norm. The Kingdom of Shame may cede its lesser duchies to shamelessness but it remains powerful and ruled by the truly shameless ones, as well as by the complacent intellectuals who govern the public discourse determining the final shape of the largely automatic social reflexes. If this shape is subordinated to the simplest clichés and the pursuit of the scandalous, it merely serves to petrify the existing social norms. In the face of such forces, the strategies of camp - including excess, parody, exaggeration, ironic kitsch, transgression, provocation, playing with inferiority - reveal themselves as toothless.

A contract fulfilled through surplus, one where the victims agree to be victims - bizarre, amusing, and acceptable to a degree - may be terminated at any point. Eventually, the shameless dancer will be called to order. Dancing till the end is allowed only in literature.

On the other hand, does not the Lawyer's cry ("We need order! This is Europe!") sound familiar? Liberal discourses were meant to create the standards of "European order" the trespassing of which is tied to shame. The shamelessness of the counter-reaction may shock us today with its strength. But looking at it from a certain distance, one may find in it quite a lot of camp - patriotic kitsch, bizarre exaggeration, and signs contradicting the context. The Hussar wings rustle and the Host bleeds among the modern skyscrapers.

Following the author, the reader of Lawyer Kraykowski's Dancer adopts the perspective of the narrator. In life, we have a tendency to become Lawyers, guarding the borders of our order with shame. Is this wrong? It all depends on the kind of order we choose to defend. 